\title{
The Impact of Quality Practices on Customer Satisfaction and Business Results: Product Versus Service Organizations
}

\author{
Lars Nilsson \\ Linkoping University, Quality and Human-Systems Engineering, SE-581 83, Linkoping, Sweden \\ Michael D. Johnson \\ University of Michigan Business School, 701 Tappan Street, Ann Arbor, MI 48109-1234, USA \\ Anders Gustafsson \\ Service Research Center, Karlstad University, Karlstad SE-651 88, Sweden
}

\begin{abstract}
Research on the differences in customer satisfaction between product and service organizations has focused on an output perspective, or how customers evaluate performance. This study takes this research inside organizations to analyze and investigate how key internal quality practices of product versus service organizations (employee management, process orientation, and customer orientation) influence customer satisfaction and business results. Using a national quality survey from 482 companies in Sweden, our analysis shows that for product organizations, internal quality practices influence customer satisfaction and business results primarily through an organization's customer orientation. For service organizations, both customer and process orientation impact customers directly, and employee management has a direct impact on business results. The research also supports the claim that organizations with a quality foundation are in a better position to adopt a customer orientation.
\end{abstract}




\section{Introduction}

A growing number of organizations use quality management as a strategic foundation for generating a competitive advantage (Reed, Lemak, \& Mero, 2000) and improving firmperformance (Hendricks \& Singhal, 1997; Lemak \& Reed, 1997; Samson \& Terziovski, 1999). Firms that have won quality awards generally outperform other firms with respect to both income measures (Hendricks \& Singhal, 1997) and stock market value (Lemak \& Reed, 1997). It is no surprise that the links among market orientation, quality practices, and performance have attracted the attention of marketing and operations management researchers alike (Ettlie \& Johnson, 1994; Flynn, Schroeder, \& Sakakibara, 1994; Kohli \& Jaworski, 1990; Narver \& Slater, 1990; Samson \& Terziovski, 1999).

Quality practices have been shown to enhance organizational performance for both product and service organizations (Powell, 1995). However, there is relatively little research on how product versus service companies differ with respect to the impact of quality practices on performance. We know little about how these two different types of organizations view what they do, how well they do it, and its consequences. Rather, the growing body of research on products versus services has focused on external customer perceptions of quality and satisfaction rather than organizational knowledge of quality practices (Anderson, Fornell, \& Rust, 1997; Edvardsson, Johnson, Gustafsson, \& Strandvik, 2000; Fornell \& Johnson, 1993; Fornell, Johnson, Anderson, Cha, \& Bryant, 1996; Huff, Fornell, \& Anderson, 1996).

The goal of this research is to examine three key internal quality practices - employee management, process orientation, and customer orientation — and their role in creating customer satisfaction and business results. We examine the similarity and differences in the effects of these practices across a large sample of product and service organizations. One of the important questions raised in our study is: Does an organization's process orientation directly impact customer satisfaction? For service firms, we expect this to be the case. But for product firms, we expect one’s process orientation to support a customer orientation or focus, which in turn impacts customer satisfaction. Another important question addressed here is: Given the critical importance of employee management in service firms, does employee management have a greater impact on performance for these firms? The answers to these and related questions are critically important for quality managers and executives who allocate resources across quality practices in their organizations.

We first examine the differences between products and services and present our framework for linking quality practices to performance. We then provide theoretical arguments and evidence as to how these links differ. We use a broad-based survey of 482 Swedish companies (product and service firms) to investigate the effects of the quality practices. While our results show that product and service firms are similar in how quality practices support each other, they also support systematic and predictable 
differences in the effects of these quality practices on customer satisfaction and business performance. The paper ends with a discussion of the implications of our results for quality management research and practice.

\section{Product versus service quality}

Service quality researchers argue that service quality and product quality are systematically different due to the inherent intangibility, inseparability of production and consumption, heterogeneity, and perishability that characterize services (Zeithaml, Parasuraman, \& Berry, 1990). Mills and Moberg (1982) categorize the differences between products and services as relating to differences in output and differences in process. Research in marketing has adopted an output perspective, or how customers evaluate the quality of a product or a service. Research in quality and operations management has taken more of a process perspective, or how an organization can work to improve the quality of a product or service. It is important, however, to understand how the output perspective relates to the internal process perspective, or its means of accomplishment within organizations. The following sections briefly review research on the output and process perspectives.

\subsection{An output perspective}

Quality experts distinguish between two general types of output quality — the degree to which a good or service provides key customer requirements, or customization, and how reliably these requirements are delivered, or reliability (Deming, 1981; Juran \& Gryna, 1988). Ishikawa and Lu (1985) make a similar argument when they separate quality into "backwardlooking”' and “forward-looking”' components. Defects and flaws in quality are called backward-looking quality, while forward-looking quality is characteristics that can become a product's sales point. Oakland (1993) distinguishes between similar components, referring to “quality" as the meeting of customer requirements, and "reliability" as the ability of a product to continue to meet the customer requirements.

Scholars in the service management tradition argue that the co-production process that typifies services makes reliability the more important quality dimension (Gronroos, 1990; Zeithaml, Parasuraman, \& Berry, 1996). Unlike goods, services are co-produced with customers at a time, and in a place, of the customer's choosing. And because service production involves more of the human resources of the firm and customers themselves, it adds greater inherent variability to the service production process. Thus, reliability should be relatively more important to maintain and improve. Initial support for the importance of service reliability in the service quality literature comes from studies using the SERVQUAL survey methodology (Parasuraman, Zeithaml, \& Berry, 1985, 1988). In their review of the SERVQUAL 
research, Zeithaml et al. (1990) note that reliability is consistently the most important service quality dimension, or largest “gap,’” to improve across service industries.

Others argue that the same co-production process makes customization relatively more important in determining customer satisfaction for services (Anderson et al., 1997; Fornell et al., 1996). Because many services are personnel-intensive and customized to suit very heterogeneous needs, customization is more important for services than for manufactured goods. However, a recent study by Johnson and Nilsson (2000) is more consistent with Parasuraman et al.'s research by showing that customization is significantly more important for products, while reliability and customization are more equally important for services. Thus, the output-based research, on the whole, suggests that improving reliability is relatively more important for services than for products.

Edvardsson, Johnson, et al. (2000) also provide evidence of systematic differences between products and services when it comes to the links from satisfaction to loyalty and financial performance. Using Swedish data, they show that the links from satisfaction, to loyalty, to profits and growth are stronger for services than for products. In particular, the links from loyalty per se to business performance are weaker for physical goods. This is attributed to the argument that, because physical goods are inventoried for sale, loyalty is more likely to be bought for products (using coupons or price incentives) as a means of moving inventory, which lowers margins. In contrast, loyalty is more likely to be earned, and thus more profitable, for service companies. Research using customer impressions also provides evidence that customer satisfaction is a leading indicator of financial performance. The national customer satisfaction indices in both the US (Ittner \& Larcker, 1996) and Sweden (Anderson, Fornell, \& Lehmann, 1994) are significant and positively related to the firms’ financial performance.

\subsection{A process perspective}

Quality practices are usually presented as a universal concept, applicable in all contexts and having a large impact on business performance. There is a substantial body of empirical research that provides support for the notion that quality management and practices improve firm performance (see Hendricks \& Singhal, 1997; Lemak \& Reed, 1997; Samson \& Terziovski, 1999). The most well-known study of quality practice is the International Quality Study (1992) conducted by Ernst Young and the American Quality Foundation. This study provides evidence that quality management has the highest impact on performance in firms that already perform well (International Quality Study, 1992). Hendricks \& Singhal $(1997,2001)$ focus their research on quality award winners. They find that many different organizational characteristics impact the benefits of quality practice. Examples of such organizational characteristic are firm size and the degree of capital intensity. Lemak and Reed (1997) investigate the impact of quality practice on performance in organizations that had been committed to quality 
management for a 5-year period. Their results indicate that a firm's market valuation increases significantly after its implementation of quality management. Overall, although there are a number of studies that have investigated the impact of quality practices on performance, these studies do not explicitly provide empirical evidence on the differences between service and product firms.

Within marketing, Kohli and Jaworski (1990) and Narver and Slater (1990) explore the impact of a market orientation on different organizational performance measures. One consistent finding is that being market-oriented does improve organizational performance for large and small firms, as well as for both product and service organizations (Wrenn, 1997). A review of the research on market orientation by Wrenn (1997) reveals that, even though this research has been conducted both in product and service environments, no thorough investigation has been made of how the effect differs between them.

Indeed, the contrasting of product and service firms is important toward our ability to reconcile differences across studies in the literature. The relationship between market orientation and customer satisfaction has not been very systematic. While, for example, McCullough, Heng, \& Khem (1986) found them to be positively related in a bank environment, this finding has not been validated across industries (Wrenn, 1997).

Within operations management, a number of studies have investigated the relationship between quality practices and performance. Most of these studies develop measurement instruments and conduct their investigations in a manufacturing environment (Ahire, Golhar, \& Waller, 1996; Flynn et al., 1994). These studies suggest that different quality practices act in synergy to influence product quality (Ahire et al., 1996). Dow, Samson, and Ford (1999) test the impact of nine quality practices on quality output in a manufacturing environment. Only three of these practices show a significantly positive impact on performance - customer focus being the most important one.

All of the studies mentioned examine the effect of quality practice on performance within a manufacturing environment. In contrast, studies by Powell (1995), Benson, Saraph, and Schroeder (1991), and Saraph, Benson, and Schroeder (1989) develop instruments for measuring quality practices in both a product and service environment. Saraph, Benson, and Schroeder do not investigate the differences of the effect of quality practice on performance, but rather how quality practices are influenced by the organizational context, such as corporate support for quality and past quality performance. They conclude that the main difference is that service firms do not have any external contextual factors (such as entry barriers and degree of external quality demand) that influence quality practice, while this is evident for product firms. One of the limitations of this research is that they exclude customer orientation or focus from their operationalization of quality practices, which we include. Powell investigates the correlation among 12 factors of total quality management and financial performance. The study concludes that there are differences between service and products organizations. For example, supplier relationships are vital 
for a product organization, while process improvements are more important for a service organization. Yet the number of organizations in Powell's study is limited to 24 product and 15 service organizations. By contrasting a much broader range of product and service firms, we hope to better understand how and why the importance of certain quality practices varies by industry and context.

\section{A framework for linking quality practices to performance}

A quality concept is essentially a business philosophy, a company ideal, or a policy statement. The business philosophy can be contrasted with its implementation reflected in the activities and behaviors of an organization. Focusing on behaviors rather than philosophical notions makes it easier to operationalize the different quality constructs. This is an important step as it helps to translate concepts into actions and thereby provide a better differentiation between different organizations.

Our proposed framework includes five general areas or constructs to consider: (1) employee management, (2) process orientation, (3) customer orientation, (4) customer satisfaction, and (5) business results. The framework is presented in Fig. 1. The first three areas are quality practices, or activities performed within an organization to improve product and process quality. Employee management is the starting point in the model. The presumption is that effective employee management, or having employees that are committed and involved, is itself a requirement for both a process orientation and a customer orientation to be effective. The other two quality practices have different starting points—one taking the processes of the organization as the focal point and the other taking the customers as the central focus. This distinction is similar, but not equal to the concept of customer and operations orientation used by Reed, Lemak, and Mongomery (1996). The core processes on which our process orientation construct focuses are those that immediately support a firm's customer orientation.

The remaining two constructs in our framework capture the results of quality practices - one from the customers' perspective in the form of customer satisfaction and the other from a business performance perspective. Generally, the framework posits that improvements in internal quality impact customer satisfaction and, in turn, business results.

One of the main conditions for successful quality practices is to engage everyone in the improvement process (Bergman \& Klefsjo , 1994). We focus on the activities taken on an organization level, such as the measurement and improvement of employee satisfaction and the involvement of employees in the development of the business, to capture the quality of an organization's employee management. The basic assumption of quality researchers is that employee satisfaction and commitment are needed to support process and customer orientation (Hackman \& Wageman, 1995).

A process is a set of activities that, taken together, produce a result of value to a customer 
(Ittner \& Larcker, 1997). A process is therefore a structure for action, the structure by which an organization does what is necessary to produce value for its customers (Davenport, 1993). There is a wide range of process management mechanisms, from process-focused improvement tools (such as process value analysis and process cycle time analysis), to the implementation of organizational structures that are based on core business processes (Ittner \& Larcker, 1997).

Frei, Kalakota, Leone, and Marx's (1999) study of the impact of process variation on financial performance in financial service institutions sheds further light on the dynamics of the impact of process orientation on customer satisfaction. They identify a lack of rigorous policies and processes as one important factor that contributes to the substantial variation in service delivery. An improvement in processes can reduce the apparent variation in the process, and can have an indirect effect on business results through increased customer satisfaction. Overall, this suggests that while process orientation, like employee management, supports a firm's customer orientation, process orientation can have a direct effect on customer satisfaction.

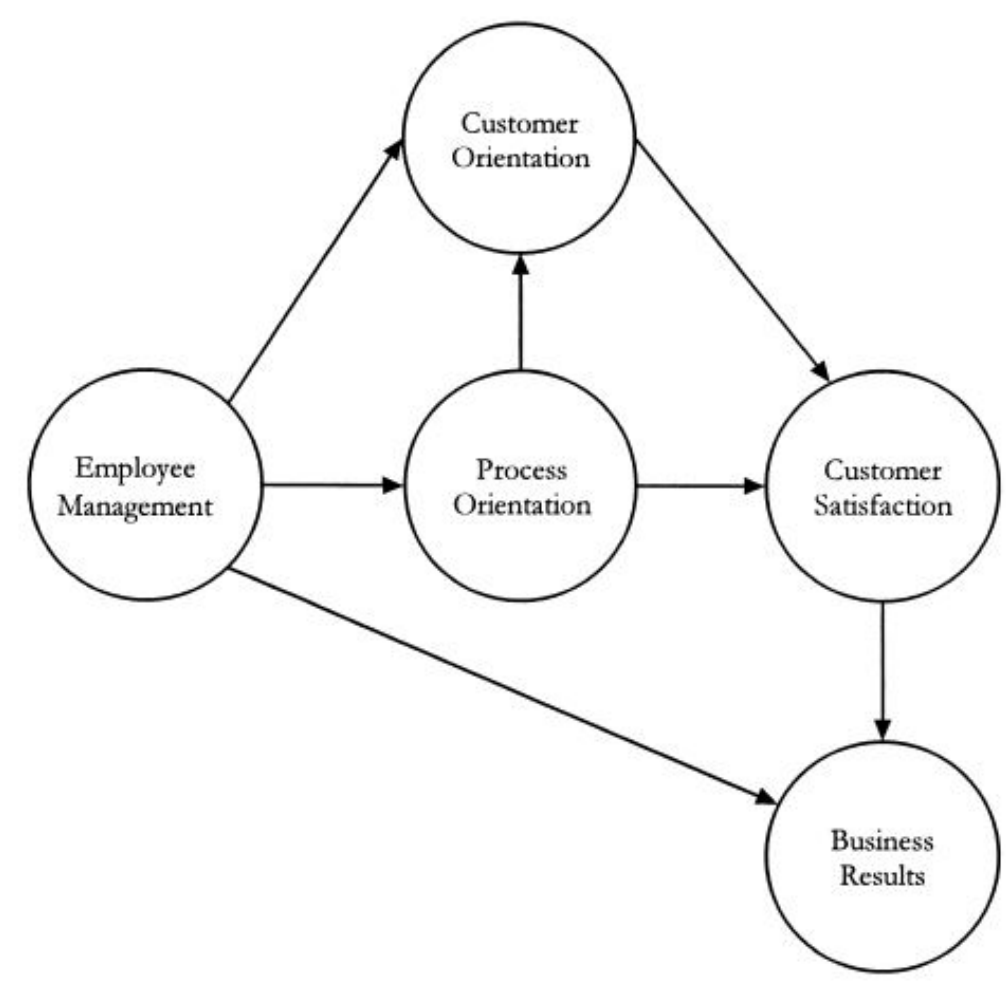

Fig. 1. A framework for linking quality practices to performance. 
In marketing, a market orientation has been defined as the organization-wide generation of market intelligence, dissemination of the intelligence across departments, and organizationwide responsiveness to it (Kohli \& Jaworski, 1990). Narver and Slater (1990) argue that a full-blown market orientation also includes a competitor orientation. However, our focus is on a firm's more specific customer orientation. A customer orientation emphasizes an organization's ability to attain customer information, analyze it to set priorities for improvement, and use these priorities to drive product and process change (Johnson, 1998; Johnson \& Gustafsson, 2000). By gaining a better understanding of customer needs and the use of this knowledge to design better products and services, a customer orientation should have a direct impact on customer satisfaction.

Research that links customer satisfaction to other business measures usually defines satisfaction as a customer's overall evaluation of the consumption experience (Johnson, 2001). Customer satisfaction research demonstrates a positive impact of satisfaction on both market value and accounting returns (Anderson et al., 1994; Ittner \& Larcker, 1996). Because of a 'ffront loading”' of customer costs and a “back loading', of revenues over the course of one’s relationship with customers, satisfied and loyal customers are more profitable (Johnson, 1998). This predicts the last link in our framework — a relationship from customer satisfaction to business results.

We expect internal quality processes related to process and customer orientation to impact business results largely through their impact on customers, or customer satisfaction. Customizing a product to meet or exceed the needs of a heterogeneous population of customer's increases customer satisfaction, which in turn increases profitability. The core processes within our process orientation construct are those that support an organization's customer orientation.

Finally, we posit a direct effect of employee management on business results. This is consistent with prior research that posits a direct relationship between job satisfaction and company performance (Iaffaldano \& Muchinsky, 1985). This effect captures a variety of factors that include, but are not limited to, increases in employee learning and competence, employee productivity and teamwork, and increased commitment and loyalty (decreased turnover).

\subsection{Research hypotheses}

As argued, services have several unique qualities relative to products (i.e., physical goods). Services are more intangible than products, making them hard if not impossible to count, measure, inventory, and test (Gro"nroos, 1990; Parasuraman et al., 1985). This also makes it difficult for customers to understand service quality and, as a result, difficult for firms to understand how consumers perceive and evaluate a service (Zeithaml et al., 1990). Unlike goods, where production and consumption are typically separated in time and place, services are co-produced at a time and place of the customer's 
choosing (Parasuraman et al., 1985). The inseparability of production and consumption for services means that service reliability is more outside the control of the firm. As a co-production process, services involve more of the human resources of the firm and customers themselves (Gronroos, 1990). There is simply a higher ratio of people to inanimate objects in the "service factory." As a result, services exhibit higher variances that cannot be directly controlled by the service process (Bateson \& Hoffman, 1999).

These differences between services and products are hypothesized to affect the impact that our different internal quality constructs have on customer satisfaction and business results. We focus on four particular relationships: (1) the effect of process orientation on customer satisfaction, (2) the effect of customer orientation on customer satisfaction, (3) the effect of customer satisfaction on business results, and (4) the effect of employee management on business results. We do not expect product and service firms to differ in how the internal quality constructs affect each other. For products and services alike, effective employee management and satisfaction are needed to support process and customer orientation (Hackman \& Wageman, 1995). Organizations working actively with employee management as the main building block in their quality strategy are in a better position to succeed with the implementation of their quality practices. Thus, we do not expect products and services to differ in the degree to which employee management impacts either process orientation or customer orientation.

Now consider the effect of process orientation on customer satisfaction. Many services are not thoroughly tested prior to market introduction (Edvardsson, Gustafsson, Johnson, \& Sanden, 2000). Consequently, the failure rate of services is high and there is a substantial variation in service delivery (Frei et al., 1999). Unlike products, where assembly plant managers are likely to carefully map out process details and rigorously adhere to the process maps, services are not subject to the same process discipline resulting in greater variation in the process (Frei et al., 1999). Importantly, the production process is more visible to service customers than to product customers. As captured in Langeard and Englier’s “servuction”' model (see Bateson \& Hoffman, 1999), service firms and the service production process can be divided in two parts — one that is visible to the consumer and a second that is invisible (the “'technical core”').

Because the production process is visible to service customers - indeed they are part of the process - process orientation should have a significant direct impact on customer satisfaction with services. In contrast, the more invisible nature of product production implies that the effect of process orientation on customer satisfaction with products is more likely to be mediated by customer orientation. That is, a process orientation creates a framework by which a customer orientation can be operationalized or built upon. As a result, the direct effect of process orientation on satisfaction should be lower, if not insignificant, for products. 
An implication of this logic is that customer orientation should have a greater impact on customer satisfaction for products compared to services. As typified by methods such as Quality Function Deployment (QFD), the translation from customer satisfaction back into its means of accomplishment is more of a chain-like series of events for products (Akao, 1990). Satisfying customers requires the identification of customers' needs (customer orientation) and translation of these needs into key process activities (process orientation) and people (employee management). In contrast, service customers are more directly intimate with and affected by a service organization’s downstream processes (Dube`, Johnson, \& Renagham, 1999). We thus predict that while process orientation has the greater direct impact on service satisfaction, customer orientation has the greater direct impact on product satisfaction.

Next we expect customer satisfaction to have a greater impact on business results for services versus products. For one, this prediction is consistent with prior research that finds the overall effect of satisfaction on performance to be greater for services (Edvardsson, Johnson, et al., 2000). Satisfaction is profitable because of its ability to maintain or increase revenues and increase margins. Because product firms have an incentive to buy loyalty (move inventory using price mechanisms), satisfaction is less profitable for products on average. Another argument is that the satisfaction-performance logic depends on the regularity of the purchase-consumption-repurchase cycle. For many services, this is a regular and often-repeated cycle (such as paying the bills, gas station services, etc.). While the same is true for many nondurable products (such as food products), this is not the case for major durable products (such as computers and automobiles). Therefore, we propose that customer satisfaction has a larger direct impact on business results for services than for products.

Finally, as argued previously, we expect employee management to have a greater direct impact on business results for service organizations. Because service organizations are relatively labor-intensive (versus physical plant-intensive), the impact from employee management to business results should be greater for service organizations. Recall that this effect captures such factors as employee learning, competence, productivity, teamwork, and commitment (decreased turnover).

We state these predictions formally as Hypotheses 1-4.

Hypothesis 1: Process orientation has a greater positive impact on customer satisfaction for service organizations than for product organizations.

Hypothesis 2: Customer orientation has a greater positive impact on customer satisfaction for product organizations than for service organizations. 
Hypothesis 3: Customer satisfaction has a greater positive impact on business results for service organizations than for product organizations.

Hypothesis 4: Employee management has a greater positive impact on business results for service organizations than for product organizations.

\section{Empirical study}

The hypotheses are tested using data from the Swedish Business Excellence Index, which is patterned after the Danish Business Excellence Index (Kristensen \& Juhl, 2000).

\subsection{Models and data}

Because quality management is a potentially unified business strategy, many of the quality practices used in organizations are strongly correlated with one another. As a result, multicollinearity can obscure the relationships between practices and performance (Dow et al., 1999). Structural Equation Modeling is well suited to handling such situations. We use partial least squares (PLS), a causal modeling method that is particularly well suited to operationalizing quality-related models such as that in Fig. 1 (Gustafsson \& Johnson, 1998). PLS is an estimation procedure that integrates aspects of principal components analysis with multiple regression (Wold, 1982). The procedure essentially extracts the first principal component from each subset of measures for the various latent variables and uses these principal components within a system of regression models. The algorithm then adjusts the principal component weights to maximize the predictive power of the model.

To test our hypotheses, two separate versions of the model in Fig. 1 were estimated — one for product organizations and one for service organizations. All constructs were modeled using reflective indicators (i.e., the indicators are created under the perspective that they all reflect the same underlying phenomenon; Chin, 1998). To evaluate the significance of the paths in the two models, jackknife estimates were generated (Chin, 1998). The general approach of jackknifing is to delete every nth case or observation, estimate the model parameters, and repeat this sample-resample procedure to generate a set of standard errors for the model parameters (Efron \& Tibshirani 1993; Hjorth, 1994). Simple $t$ statistics are then computed to determine whether the parameters are different from zero and different from model to model. Following Tukey’s guidelines (see Fornell \& Barclay, 1993), 5\% of the sample was removed during the re-sampling procedure, resulting in 20 subsamples per model.

\subsection{Survey instrument}


The survey instrument was a four-page mail survey sent to the CEO in different Swedish organizations in the competitive sector during November 1999. The survey instrument was developed following the EFQM Excellence model and included 51 items. Each item was scored on a 10-point scale ranging from “"completely disagree” to "completely agree”, (except for a section containing background variables for categorizing the organization). For the purpose of this study, 17 items were used to operationalize the latent constructs; 11 for the three internal quality constructs and 6 for the two performance constructs (see Table 1).

\subsection{Firm sample}

In the Swedish Business Excellence Index for 1999, 1658 organizations participated. The response rate for this mail survey was $26 \%$, a level that is typical for this kind of study. An investigation of some of the organizations that choose not to participate in this study revealed that they did not adhere to a systematic quality strategy, while other organizations did not feel that they had time to participate in this kind of survey. The participating organizations are categorized in five industry categories: (1) Industry, Manufacturing, and Supply (NACE 01-44); (2) Construction (NACE 45); (3) Trade, Transportation, and Communication (NACE 50-64); (4) Bank and Insurance (NACE 65- 67); and (5) Service (NACE 70-99). The organizations in our sample are also categorized according to size in five classes. For this research project, a subsample of organizations suitable for the purpose of this study was chosen. Two categories were chosen: Industry (1) and Service (5). After a validity check of the constructs3 for quality practices, it was decided that only organizations with more than 50 employees were to be included in the study. In the end, 360 product and 122 service organizations were used to estimate the product and service models, respectively.4.4. Operationalization of the constructs

The constructs used in this research are sufficiently general as to apply to both a product and a service context. It is arguably more appropriate to use more abstract, inclusive dimensions when making cross-industry comparisons between relatively "noncomparable”' goods and services (Johnson \& Fornell, 1991). And many of the proposed constructs for quality practices have been developed only for manufacturing companies (see Ahire et al., 1996; Samson \& Terziovski, 1999). The constructs proposed by Saraph et al. (1989) are tested and validated in both a service and product context. Unfortunately, their framework does not include customer orientation. And while their operationalization of process management relies heavily on the usage of statistical methodologies, our process orientation construct focuses more on the core processes that relate to customer requirements and thus support a firm's customer orientation. 
Table 1

Construct measures

\begin{tabular}{|c|c|}
\hline Constructs & Description of measures \\
\hline \multicolumn{2}{|c|}{ Employee management } \\
\hline $\mathrm{EM}_{1}$ & The competence of the employees is maintained and developed in a systematic way. \\
\hline $\mathrm{EM}_{2}$ & The employees participate systematically in the development of the business. \\
\hline $\mathrm{EM}_{3}$ & The factors that have a positive impact on employee satisfaction are defined. \\
\hline $\mathrm{EM}_{4}$ & There are systematic goals for employee satisfaction, loyalty, tumover, and absence. \\
\hline $\mathrm{EM}_{5}$ & $\begin{array}{l}\text { Employee satisfaction is analyzed and the results are the target of } \\
\text { continuous improvement. }\end{array}$ \\
\hline \multicolumn{2}{|c|}{ Process orientation } \\
\hline $\mathrm{PO}_{1}$ & Core processes are identified and documented. \\
\hline $\mathrm{PO}_{2}$ & The core processes are measured and evaluated. \\
\hline $\mathrm{PO}_{3}$ & $\begin{array}{l}\text { Co-workers are continuously stimulated and motivated to participate } \\
\text { in development and improvement of the core processes. }\end{array}$ \\
\hline \multicolumn{2}{|c|}{ Customer orientation } \\
\hline $\mathrm{CO}_{1}$ & The factors creating customer satisfaction are clearly defined. \\
\hline $\mathrm{CO}_{2}$ & There are systematic goals for customer satisfaction, loyalty, and complaints. \\
\hline $\mathrm{CO}_{3}$ & $\begin{array}{l}\text { Analysis of customer satisfaction is made and the results are followed } \\
\text { by continuous improvements. }\end{array}$ \\
\hline \multicolumn{2}{|c|}{ Customer satisfaction } \\
\hline $\mathrm{CS}_{1}$ & During the last years, customer satisfaction has increased. \\
\hline $\mathrm{CS}_{2}$ & During the last years, customer complaints have decreased. \\
\hline \multicolumn{2}{|c|}{ Business results } \\
\hline $\mathrm{BR}_{1}$ & During the last years, the business result has improved. \\
\hline $\mathrm{BR}_{2}$ & During the last years, the effectiveness of the organization has improved. \\
\hline $\mathrm{BR}_{3}$ & During the last years, the use of resources has improved. \\
\hline $\mathrm{BR}_{4}$ & $\begin{array}{l}\text { During the last years, the business result has improved compared to other } \\
\text { similar businesses. }\end{array}$ \\
\hline
\end{tabular}

As shown in Table 1, employee management is operationalized as a five-item construct, while both process and customer orientation are three-item constructs. Our constructs for business results and customer satisfaction are measured indirectly by asking the management of the participating organizations. Subjective measures of performance are commonly used in research on companies and the business units of large companies (Powell, 1995). Previous studies have found a strong correlation between subjective assessments and their objective counterparts (Powell, 1992). In this study, we use a two-item construct to measure customer satisfaction and a four-item construct to measure business results. However, in order to verify that our business performance results are robust, we conduct a subsequent analysis using two objective performance measures.

\subsection{Results}


The proposed model was estimated using PLS across individual firms separately for product ( $\mathrm{n}=$ $360)$ and service ( $n=122$ ) organizations. We first discuss the quality of the measurement models and then examine the latent variable model results.

The first step in assessing the measurement models involves testing the reliability of each measured variable to ensure that the measurement variables (MVs) load meaningfully to their related constructs. Overall, the MV loadings are all relatively large and positive. The loadings of all MVs should exceed .707 to ensure that at least half of the variance in the observed variable is shared with the construct (the squared correlation equals the variance explained, where $.7072=50 \%$; see Hulland, 1999). The proportion of this shared variance to the total variance of the underlying construct is called the communality of the construct (Fornell \& Cha, 1994). As can be seen in Table 2, in the model for product organizations, all the loadings exceed the recommended threshold value, while 16 of the 17 loadings in the service model exceed the threshold value. The exception is the loading for the fifth item in the employee management construct (loading EM5=.661). The research practice is to keep the item in the analysis if the loading exceeds .5, if there are good theoretical reasons to do so. In this case, the item is retained in the analysis in order to keep the models directly comparable.

\section{Table 2}

Loadings for all items in the two estimated models

\begin{tabular}{llc}
\hline Indicator & Products & Services \\
\hline $\mathrm{EM}_{1}$ & .7423 & .8497 \\
$\mathrm{EM}_{2}$ & .7228 & .7817 \\
$\mathrm{EM}_{3}$ & .8185 & .8383 \\
$\mathrm{EM}_{4}$ & .8009 & .7462 \\
$\mathrm{EM}_{5}$ & .7629 & .6611 \\
$\mathrm{PO}_{1}$ & .8596 & .8854 \\
$\mathrm{PO}_{2}$ & .8929 & .9029 \\
$\mathrm{PO}_{3}$ & .8426 & .8981 \\
$\mathrm{CO}_{1}$ & .8288 & .8208 \\
$\mathrm{CO}_{2}$ & .8972 & .8670 \\
$\mathrm{CO}_{3}$ & .8663 & .8474 \\
$\mathrm{CS}_{1}$ & .9399 & .9057 \\
$\mathrm{CS}_{2}$ & .8359 & .8671 \\
$\mathrm{BR}_{1}$ & .8278 & .8408 \\
$\mathrm{BR}_{2}$ & .8813 & .8862 \\
$\mathrm{BR}_{3}$ & .8635 & .8027 \\
$\mathrm{BR}_{4}$ & .7829 & .7333 \\
\hline
\end{tabular}

In addition to the reliability of the individual items or MVs, we need to study the composite reliability of the constructs. To investigate the internal consistency for a given block of indicators, the $r$ coefficient developed by Werts, Linn, and Joreskog can be calculated (see Chin, 1998). To design 
constructs with high internal consistency, researchers have suggested that the value of $r$ should be greater than .70. The r coefficients for the constructs of the two separate models are presented in Table 3. All coefficients are higher than the proposed threshold of .70, and this supports the ability of the measures used in this research to operationalize the various latent constructs.

To check the validity of the model, the Average Variance Extracted (AVE) is used (Fornell \& Larcker, 1981). The AVE measures the amount of variance that is captured by the constructs in relation to the amount of variance due to measurement error (Fornell \& Cha, 1994). To ensure discriminant validity of the constructs, the AVEs of the latent variables should be greater than the square of the correlations among the latent variables (Chin, 1998). In PLS, the correlation matrix of the latent constructs, where the diagonal elements are replaced by the square root of the computed AVEs, is used to make this comparison. Higher values for the diagonal elements compared to the off diagonal elements suggest good discriminant validity. As can be seen in Table 4a and b, this is the case for both the product and service models, which ensures that both models show good discriminant validity.

\subsection{Testing the hypotheses}

The two estimated models are presented in Fig. 2a and b, where the significant paths are highlighted and the ability of the model to explain variation in the endogenous variable is indicated for each construct. The models for product and service organizations explain $25 \%$ and $37 \%$ of the variation in business results, respectively. Consistent with previous research, the explanatory power is larger for the service model (Edvardsson, Johnson, et al., 2000). Of the 14 proposed paths in the two models, 13 are significant (using adjusted t tests and $\mathrm{P}<.05$ ).

The jackknife estimates also allow us to test whether the parameters are significantly different between the two models, the results of which are presented in Table 5. Hypothesis 1 predicts that process orientation has a direct impact on customer satisfaction for services, while this effect is small or nonexistent in product firms. The path coefficients for the two models support this prediction. In the service model, the path coefficient between process

Table 3

Assessment of the composite reliability of the constructs

\begin{tabular}{lll}
\hline$\rho$ Coefficient & Products & Services \\
\hline Employee management & .879 & .884 \\
Process orientation & .899 & .924 \\
Customer orientation & .899 & .882 \\
Customer satisfaction & .883 & .880 \\
Business results & .905 & .889 \\
\hline
\end{tabular}


Table 4

\begin{tabular}{|c|c|c|c|c|c|}
\hline & EM & PO & $\mathrm{CO}$ & $\mathrm{CS}$ & $\mathrm{BR}$ \\
\hline \multicolumn{6}{|c|}{ (a) Assessment of the validity of the product model (AVE) } \\
\hline EM & .770 & & & & \\
\hline PO & .625 & .865 & & & \\
\hline $\mathrm{CO}$ & .545 & .503 & .865 & & \\
\hline $\mathrm{CS}$ & .384 & 321 & .508 & .889 & \\
\hline $\mathrm{BR}$ & .355 & 379 & .309 & .458 & .840 \\
\hline \multicolumn{6}{|c|}{ (b) Assessment of the validity of the service model (AVE) } \\
\hline EM & .778 & & & & \\
\hline PO & .601 & .895 & & & \\
\hline $\mathrm{CO}$ & .551 & .525 & .845 & & \\
\hline $\mathrm{CS}$ & .456 & .411 & .438 & .887 & \\
\hline $\mathrm{BR}$ & .537 & .483 & .371 & .493 & .818 \\
\hline
\end{tabular}

orientation and customer satisfaction is $.250(\mathrm{P}<.05)$, while the path is .087 (not significant) in the product model. The two paths are also significantly different from each other. Thus, our analysis supports Hypothesis 1.

Hypothesis 2 predicts that the effect of a customer orientation on customer satisfaction is greater for products than for services. The path coefficient is .463 $(\mathrm{P}<.01)$ for product organizations and $.36(\mathrm{P}<$ .01) for services, and there is a significant difference between these two coefficients $(\mathrm{P}<.01)$. Customer orientation on the organizational level has a higher impact on customer satisfaction for products than it has for services, which supports

Hypothesis 2. In contrast, studying the path from customer satisfaction to business results for the two models reveals that there is no statistical significance between the coefficients.

The path coefficient is .378 $(\mathrm{P}<.05)$ for product organizations and $.314(\mathrm{P}<.05)$ for services. Thus, Hypothesis 3 is not supported. Possible reasons for the lack of support are described in Section 4.7 of the paper. Hypothesis 4 predicts that employee management has a higher impact on business results for services than for products. Comparing the path coefficients of the two models supports this prediction. The path coefficients are significantly positive for both models (.210 for products and .394 for services), and significantly different from each other $(\mathrm{P}<.01)$. Overall, our analysis supports Hypotheses 1,2 , and 4, but not Hypothesis 3.

\subsection{Validating the results}

The model estimations have thus far used subjective measures of quality practices and business results from the mail survey. One way to validate our results is to run the same models using more 
objective financial data to measure the business results construct. The problem with using objective measures is that we are working with a very heterogeneous sample and can expect significant industry differences in capital structures and accounting conventions (Powell, 1992). There are also a large number of exogenous factors that affect profits and revenue growth that are not specified in our model. It will be important, therefore, to focus more on the relative differences between products and services to test our predictions (Edvardsson, Johnson, et al., 2000).

The financial data in our analysis originate from UC (translated from Swedish as the Information Bureau), which is Sweden's largest and leading business and credit information agency. The results construct is operationalized for each firm using two measures: profit margin and return on capital employed. Each firm's profit margin and revenue growth was mean-centered by industry to help control for industry-level differences. We used the two-digit NACE code to identify what industry each company belonged to.

The new performance construct's communality is $75 \%$ for both products and services, which well exceeds the formally stated value of $50 \%$. One of the loadings in the business results construct for services is, however, below the criterion of .5. Although the loading for the profit margin variable is only .45 , we retain the measure because the loading is not far from the criterion and it makes the models more comparable.

We focus our discussion on the results involving the direct paths from employee management and customer satisfaction to business results. (The path coefficients involving the three internal quality constructs and customer satisfaction are essentially identical to those in Fig. 2a and b.) Overall, the results involving the relative effects of employee management on objective measures of business results are consistent with those reported for the self-reported measures. Employee management has a greater impact on business results for service companies, where the path coefficient of .146 is positive and significant (P $<.10$ ) than for product companies, where the path coefficient of .016 is nonsignificant.

Recall that we expected customer satisfaction to have a greater impact on business results for services. Using our self-reported survey measures, this prediction was not supported. Indeed, the directional effect was just the opposite, where satisfaction had a larger directional effect on business results for the product companies (.378 for products versus .314 for services). The path coefficients involving customer satisfaction and our objective performance measures follow the very same pattern. The impact of customer satisfaction on business results is .072 for product companies and .003 for service companies (both nonsignificant). Again, we are more interested in the relative size of the path coefficients given the wide range of exogenous variables that likely explain performance.

Our validation of the use of subjective measures of business results concerns two of our four hypotheses. Overall, and consistent with our primary analysis using the survey data only, using objective 
measures of business results (margins and return on capital employed) supports Hypothesis 4, but not Hypothesis 3.

Table 5

Significance testing of differences between the product and service model

\begin{tabular}{lllll}
\hline Effect of & On & Products & Services & Significant difference \\
\hline EM & PO & .626 & .601 & Not significant \\
EM & CO & .380 & .369 & Not significant \\
EM & BR & .210 & .394 & Significant $(P<.01)$ \\
PO & CO & .265 & .304 & Not significant \\
PO & CS & .088 & .250 & Significant $(P<.05)$ \\
CO & CS & .463 & .306 & Significant $(P<.01)$ \\
CS & BR & .378 & .314 & Not significant \\
\hline
\end{tabular}

\section{Discussion and conclusions}

Quality management provides a strategic foundation for generating a competitive advantage for many organizations (Reed et al., 2000). There is a substantial body of empirical research that supports quality management's role toward improving firm performance. However, it is also becoming clear that the “one-size-fits-all”' approach that has pervaded the quality management literature is flawed (Lemak \& Reed, 2000). Our point of departure is that quality management processes work differently depending on the product versus service nature of the firm and associated production processes. An important contribution of this research is our framework for linking quality practices to performance. The framework allows us to theoretically identify how product and service companies are both similar and different with respect to the effects of quality practices on customers and business results.

Another important contribution is that we use a large sample of product and service firms to show their empirical similarities and differences. For both product and service companies, internal quality practices support each other in a like fashion. Employee management supports both a firm's process and customer orientation, while process orientation also directly supports customer orientation. This provides basic support for the argument that organizations that have good internal quality management systems are typically in a better position to adopt a customer orientation (Johnson \& Gustafsson, 2000).

We also find systematic differences between products and services. In manufacturing organizations, both employee management and process orientation have their effects on customer satisfaction through a firm's customer orientation. That is, customers are only interested in the output of the process. In service organizations, both process orientation and customer orientation have direct effects on customer satisfaction. This is due to the role of the customer as a co-producer and the fact that a service is produced and consumed at the same time. The production process is simply more visible to service customers, and it is also one in which they are directly involved. We also find broad-based support for the prediction that employee management has a greater direct effect on business performance 
for services. Satisfying and creating committed employees is important for all companies, but more so for services where frontline service providers are a service company’s primary asset.

Overall, our results support the notion that customer satisfaction and subsequent profitability are a more chain-like set of events for products. Consistent with quality improvement tools such as QFD (Akao, 1990; Ettlie \& Johnson, 1994; Gustafsson \& Johnson, 1998), bridging the gap between external customers and internal operations involves a translation of the voice of the customer into the voice of the company. However, for services, the translation is more complex because customers are part of a service factory and employee management mhas a direct impact on business results (Dube`et al., 1999).

Our unexpected finding was that customer satisfaction did not have a greater impact on business results for services. In fact, the effect was directionally, but not significantly, in the opposite direction using both the self-reported measures of business performance and objective performance measures. There are at least two possible explanations as to why the results of Edvardsson, Johnson, et al. (2000) are not replicated here. First, this study only has two performance constructs, customer satisfaction and business results, whereas Edvardsson, Johnson, et al. included loyalty as a separate construct. If only the direct effects of customer satisfaction on business results are compared, Edvardsson, Johnson, et al. also found no statistical difference. Second, our measures of customer satisfaction come from the companies, while Edvardsson, Johnson, et al. used measures from customers themselves.

\subsection{Implications for managers}

As noted above, our study provides managers with both a framework for understanding how quality processes affect each other and some empirical generalizations about differences between product and service organizations. The framework is useful on two different levels, an industry level and a company level. At the industry level, the framework helps us to understand the linkages between practices and performance and provide theoretical explanations as to why a certain practice may work well in one context, but not another. At the company level, the framework can be used to evaluate how different quality improvements are linked to customer satisfaction and business performance.

This research can also be seen in the light of the service infusion in manufacturing companies. The service content of various products is increasing, not least in manufacturing industries (Wise \& Baumgartner, 1999). Since quality practices have different impacts inservice and manufacturing firms, a firm’s quality strategy must evolve accordingly. Depending on one’s service versus product content, investments in quality will have very different impacts across organizations or business units and over time. An appealing avenue for future research is to follow manufacturing organizations over time and study the changing role of quality practices as the service content of the organizations' offerings 
increases. This would help researchers and managers alike to better understand how a firm's quality strategy should evolve over time.

\subsection{Limitations of the study}

Our primary analysis is based on self-reported company measures for all of our constructs, both internal and external to the organization. Measuring management perception of quality practices on a 10point Likert scale captures the perceived extent of quality practice in the organization. Our belief is that the CEO in each organization is the individual who is best suited to answer a survey that covers both quality practice and business results. It is also an accepted research approach.

However, Gerhart, Wright, Mc Mahan, and Snell (2000) raise the question of using only one informant per organization. Such an approach makes it impossible to estimate the measurement error due to the sample of informants used. We acknowledge this limitation, although we believe it is not severe. In Gerhart et al.'s study, the average number of employees in the studied organizations was 46,396. For such large organizations, we agree that it is almost impossible for one informant to have sufficient knowledge about the organizations’ quality practices. However, Huselid and Becker (2000) conclude that the information problem is less of a concern in smaller organizations. In our sample, 93\% of the organizations have fewer than 500 employees. Our companies are thus considerably smaller than Gerhart et al.'s.

Our analysis also uses self-reports for both customer satisfaction and business performance. Subjective performance measures are widely accepted in organizational research (see Azaranga, Gonzalez, \& Reavill, 1998; International Quality Study, 1992; Powell, 1995). One problem with using objective performance is that it is often at the wrong level of aggregation and out-of-date (Boyd, Dess, \& Rasheed, 1993). However, we verified our results by replacing our self-reported business performance measures with objective measures (profit margins and return on capital employed). The relative differences that we observed between products and services were quite consistent.

Concerning customer satisfaction, no direct customer measures were available. Our results are, however, consistent with other studies that use direct measures of customer satisfaction. Johnson and Nilsson's (2000) finding that reliability is relatively more important for service satisfaction than product satisfaction is consistent with our finding that process management, where reliability is either assured or breaks down, has a direct impact on customers. Going forward, it will be important to incorporate measures from different sources. This will require asking multiple respondents in each organization about their quality practice, asking customers about their degree of customer satisfaction and customer loyalty, and getting better objective financial data on business performance.

This study has been conducted in Sweden with a sample of Swedish firms. One question to ask is: Are there any cultural differences concerning quality practices that would influence the interpretation of 
the results of our study? In a cross-cultural quality management study of 12 countries, the US, Japan, and Sweden are on the same high level with respect to their cultural approach toward quality management (Kroslid, 1999). These countries were considered more advanced than other countries such as Korea and China. This makes Sweden a good context for investigation. However, it is still important to conduct a cross-cultural study that investigates differences in the relationship between quality practice and performance going forward. 

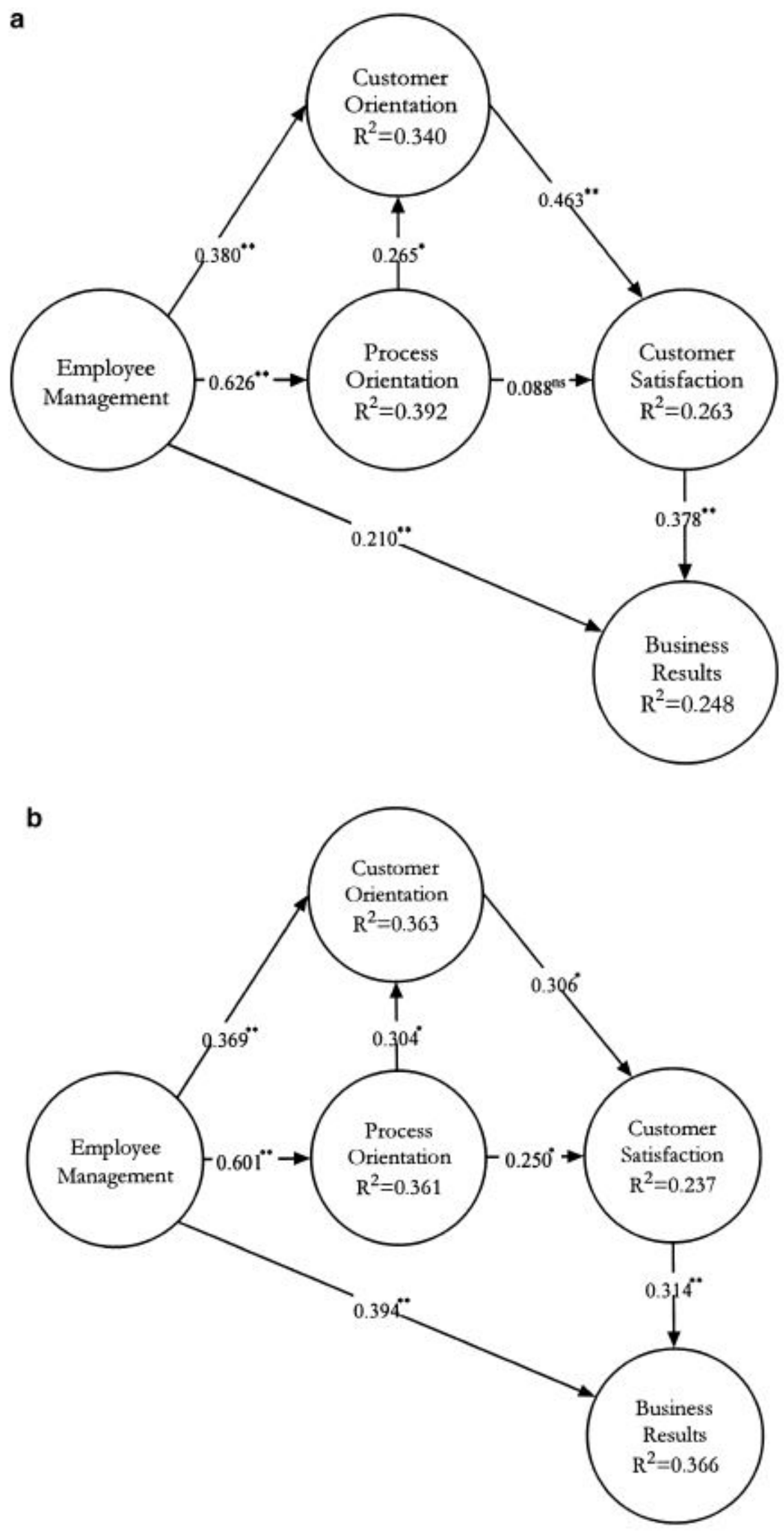


\section{References}

1. Ahire, S. L., Golhar, D. Y., \& Waller, M. A. (1996). Development and validation of TQM implementation constructs. Decision Sciences, 27, 23 - 56.

2. Akao, Y. (1990). QFD: integrating customer requirements into product design. Cambridge, MA: Productivity Press. Anderson, E. W., Fornell, C., \& Lehmann, D. R. (1994). Customer satisfaction, market share, and profitability. Journal of Marketing, 58, 53 - 66.

3. Anderson, E. W., Fornell, C., \& Rust, R. T. (1997). Customer satisfaction, productivity, and profitability: differences between goods and services. Marketing Science, 16, 129 - 145.

4. Azaranga, M. R., Gonzalez, G., \& Reavill, L. (1998). An empirical investigation of the relationships between quality improvement techniques and performance - a Mexican case. Journal of Quality Management, 3, 265 - 292.

5. Bateson, J. E. G., \& Hoffman, K. D. (1999). Managing services marketing. Forth Worth, TX: Dryden Press. Benson, G. P., Saraph, J. V., \& Schroeder, R. G. (1991). The effects of organizational context on quality management: an empirical investigation. Management Science, 37, 1107 - 1124.

6. Bergman, B., \& Klefsjoo, B. (1994). Quality: from customer needs to customer satisfaction. Lund, Sweden: Studentlitteratur.

7. Boyd, B. K., Dess, G. G., \& Rasheed, A. M. A. (1993). Divergence between archival and perceptual measures of the environment: causes and consequences. Academy of Management Review, 17, 99 $-117$.

8. Chin, W. W. (1998). The partial least squares approach to structural equation modeling. In: G. A. Marcoulides (Ed.), Modern methods for business research. New Jersey: LEA.

9. Davenport, T. H. (1993). Managing in the new world of process. Public Productivity and Management Review, 18, 133 - 147.

10. Deming, W. E. (1981). Management of statistical techniques for quality and productivity. New York: New York University.

11. Dow, D., Samson, D., \& Ford, S. (1999). Exploding the myth: do all quality management practices contribute to superior quality performance? Production and Operations Management, 8, 1 - 27.

12. Dubee`, L., Johnson, M. D., \& Renaghan, L. M. (1999). Adapting the QFD approach to extended service transactions. Production and Operations Management, 8, 301 - 317.

13. Edvardsson, B., Gustafsson, A., Johnson, M. D., \& Sandee'n, B. (2000). New service development and innovation in the new economy. Lund, Sweden: Studentlitteratur.

14. Edvardsson, B., Johnson, M. D., Gustafsson, A., \& Strandvik, T. (2000). The effects of satisfaction and loyalty on profit and growth: products versus services. Total Quality Management, 11, 917 927.

15. Efron, B., \& Tibshirani, R. J. (1993). An introduction to the bootstrap. London: Chapman \& Hall.

16. Ettlie, J. E., \& Johnson, M. D. (1994). Product development benchmarking versus customer focus in applications of Quality Function Deployment. Marketing Letters, 5, 107 - 116.

17. Flynn, B. B., Schroeder, R. G., \& Sakakibara, S. (1994). A framework for quality management research and an associated measurement instrument. Journal of Operations Management, 11, 339 $-366$.

18. Fornell, C., \& Barclay, D. (1993). Jackknifing in PLS. Ann Arbor, MI: University of Michigan Business School (Research note).

19. Fornell, C., \& Cha, J. (1994). Partial least squares. In: R. P. Bagozzi (Ed.), Advanced methods of marketing research (pp. 52 - 78). Cambridge, MA: Blackwell. 
20. Fornell, C., \& Johnson, M. D. (1993). Differentiation as a basis for explaining customer satisfaction across industries. Journal of Economic

Psychology, 14, 681 - 696.

21. Fornell, C., Johnson, M. D., Anderson, E. W., Cha, J., \& Bryant, B. E. (1996). The American Customer Satisfaction Index: nature, purpose and findings. Journal of Marketing, 60, 7 - 18.

22. Fornell, C., \& Larcker, D. (1981). Evaluating structural equation models with unobservable variables and measurement error. Journal of Marketing Research, 18, 39 - 50.

23. Frei, F. X., Kalakota, R., Leone, A. J., \& Marx, L. M. (1999). Process variation as a determinant of bank performance: evidence from the retail banking study. Management Science, 45, 1210-1220.

24. Gerhart, B., Wright, P. M., Mc Mahan, G. C., \& Snell, S. A. (2000). Measurement error in research on human resources and firm performance: how much error is there and how does it influence effect size estimates? Personnel Psychology, 53, 803 - 834.

25. Gronroos, C. (1990). Service management and marketing: managing the moments of truth in service competition. Lexington, MA: Lexington Books.

26. Gustafsson, A., \& Johnson, M. D. (1998). Bridging the quality satisfaction gap. Quality Management Journal, 4, $27-43$.

27. Hackman, J. R., \& Wageman, R. (1995). Total quality management — empirical, conceptual, and practical issues. Administrative Science Quarterly, 40, 309 - 342.

28. Hendricks, K. B., \& Singhal, V. R. (1997). Does implementing an effective TQM program actually improve operating performance? Empirical evidence from firms that have won quality awards. Management Science, 43, 1258 - 1274.

29. Hendricks, K. B., \& Singhal, V. R. (2001). Firm characteristics, total quality management, and financial performance. Journal of Operations Management, 19, 269 - 285.

30. Hjorth, J. S. U. (1994). Computer-intensive statistical methods: validation model selection and boostrap. London: Chapman \& Hall.

31. Huff, L., Fornell, C., \& Anderson, E. (1996). Quality and productivity: contradictory and complementary. Quality Management Journal, 4, 22 - 39.

32. Hulland, J. (1999). Use of partial least squares (PLS) in strategic management research: a review of four recent studies. Strategic Management Journal, 20, 195 - 204.

33. Huselid, M. A., \& Becker, B. E. (2000). Comment on "Measurement error in research on human resources and firm performance: how much error is there and how does it influence effect size estimates?” by Gerhart, Wright, Mc Mahan, and Snell. Personnel Psychology, 53, 835 - 854.

34. Iaffaldano, M. T., \& Muchinsky, P. M. (1985). Job satisfaction and job performance: a meta analysis. Psychological Bulletin, 97, 251 - 273.

35. International Quality Study. (1992). Best practices report: an analysis of management practices that impact performance. A joint project of Ernst Young and the American Quality Foundation. Cleveland, OH: American Quality Foundation.

36. Ishikawa, K., \& Lu, D. J. (1985). What is total quality control? The Japanese way. Englewood Cliffs, NJ: Prentice-Hall.

37. Ittner, C. D., \& Larcker, D. F. (1996). Measuring the impact of quality initiatives on firm financial performance. In: D. B. Fedor, \& S. Ghosh (Eds.), Advances in the management of organizational quality, vol. 1. London: JAI Press.

38. Ittner, C. D., \& Larcker, D. F. (1997). The performance effects of process management techniques. Management Science, 43, 522 - 534.

39. Johnson, M. D. (1998). Customer orientation and market action. Upper Saddle River, NJ: PrenticeHall. 
40. Johnson, M. D. (2001). Customer satisfaction. In: N. J. Smelser, \& P. B. Baltes (Eds.), International encyclopedia of the social and behavioral sciences. Amsterdam, the Netherlands: Elsevier (forthcoming).

41. Johnson, M. D., \& Fornell, C. (1991). A framework for comparing customer satisfaction across individuals and product categories. Journal of Economic Psychology, 12, 267 - 286.

42. Johnson, M. D., \& Gustafsson, A. (2000). Improving customer satisfaction, loyalty and profit: an integrated measurement and management system. San Francisco, CA: Jossey-Bass.

43. Johnson, M. D., \& Nilsson, L. (2000). The impact of reliability and customization on customer satisfaction for goods versus services. Ann Arbor, MI: University of Michigan Business School (Working Paper

No. 00-027).

44. Juran, J. M., \& Gryna, F. M. (1988). Juran's quality control handbook (4th ed.). New York: McGrawHill.

45. Kohli, A. K., \& Jaworski, B. J. (1990). Market orientation: the construct, research propositions, and managerial implications. Journal of Marketing, 54, 1 - 18.

46. Kristensen, K., \& Juhl, H. J. (2000). Beyond the bottom line: measuring stakeholder value. In: B. Edvardsson, \& A. Gustafsson (Eds.), The Nordic school of quality management. Lund, Sweden: Studentlitteratur.

47. Kroslid, D. (1999). In search of quality management: rethinking and reinterpreting. Doctoral dissertation, Linkoping University, Sweden.

48. Lemak, D. J., \& Reed, R. (1997). Commitment to total quality management: is there a relationship with firm performance? Journal of Quality Management, 2, 67 - 86.

49. Lemak, D. J., \& Reed, R. (2000). An application of Thompson's typology to TQM in service firms. Journal of Quality Management, 5, 67 - 83.

50. McCullough, J., Heng, L. S., \& Khem, G. S. (1986). Measuring the marketing orientation of retail operations of international banks. International Journal of Bank Marketing, 4, 9 - 18.

51. Mills, P. K., \& Moberg, D. J. (1982). Perspectives of the technology of service operations. Academy of Management Review, 7, 467 - 478.

52. Narver, J. C., \& Slater, S. F. (1990). The effect of a market orientation on business profitability. Journal of Marketing, 54, 20 - 35.

53. Oakland, J. S. (1993). Total quality management. New Jersey, USA: Nichols Publishing.

54. Parasuraman, A., Zeithaml, V. A., \& Berry, L. L. (1985). A conceptual model of service quality and its implications for future research. Journal of Marketing, 49, $41-50$.

55. Parasuraman, A., Zeithaml, V. A., \& Berry, L. L. (1988). SERVQUAL: a multi-item scale for measuring consumer perceptions of service quality. Journal of Retailing, 64, $12-40$.

56. Powell, T. C. (1992). Organizational alignment as competitive advantage. Strategic Management Journal, 13, 119 - 134.

57. Powell, T. C. (1995). Total quality management as competitive advantage: a review and empirical study. Strategic Management Journal, 16, 15 - 37.

58. Reed, R., Lemak, D. J., \& Mero, N. P. (2000). Total quality management and sustainable competitive advantage. Journal of Quality Management, 5, 5 - 26.

59. Reed, R., Lemak, D. J., \& Mongomery, J. C. (1996). Beyond process: TQM content and firm performance. Academy of Management Review, 21, 173 - 202.

60. Samson, D., \& Terziovski, M. (1999). The relationship between total quality management practices and operational performance. Journal of Operations Management, 17, 393 - 409.

61. Saraph, J. V., Benson, P. G., \& Schroeder, R. G. (1989). An instrument for measuring the critical factors of quality management. Decision Sciences, 20, 810 - 829. 
62. Wise, R., \& Baumgartner, P. (1999). Go downstream: the new profit imperative in manufacturing. Harvard Business Review, 77, 133 - 141.

63. Wold, H. (1982). Systems under indirect observation using PLS. In: C. Fornell (Ed.), A second generation of multivariate analysis methods. New York: Praeger.

64. Wrenn, B. (1997). The market orientation construct: measurement and scaling issues. Journal of Marketing, 61, 31 - 54.

65. Zeithaml, V. A., Parasuraman, A., \& Berry, L. L. (1990). Delivering service quality. New York: The Free Press.

66. Zeithaml, V. A., Parasuraman, A., \& Berry, L. L. (1996). The behavioral consequences of service quality. Journal of Marketing, 60, 31 - 46. 